\title{
Establishment of Demand and Supply Equilibrium Model for the Employment Quality Improvement in Private Vocational Colleges under the Perspective of Career Planning
}

\author{
Based on the Survey Data of Employment Quality of Graduates in Grade 2016 of Lingnan \\ Institute of Technology in Guangdong
}

\author{
Qing Qing \\ Lingnan Institute of Technology \\ Guangzhou, China 510663
}

\begin{abstract}
According to the survey data of employment quality of graduates in grade 2016 of Lingnan Institute of Technology in Guangdong, the employment quality has been analyzed through three measurement indexes of employment quality, namely monthly income, specialty relevance and satisfaction degree of current employment status. The current situation of supply and demand of the employment guidance service is analyzed by virtue of the survey data of employment guidance service. The demand and supply are analyzed through the concept of supply and demand balance in economics. On one hand, I stress using the theory of career planning to help students get a clear understanding of them, know clearly about their demands, have the impetus of learning and proactively learn various courses provided by the school, making the sound course system play the role of improving employment quality. On the other hand, a sound course system that complies with the practical situation of private vocational colleges is provided according to the demands of students and the society, in order to provide effective "supply" for students.
\end{abstract}

Keywords - career planning; employment quality improvement; supply and demand equilibrium model

\section{INTRODUCTION}

To comprehensively and systematically reflect the practical situation of employment work of universities, the Office of the Ministry of Education has issued the Notice of the Compilation and Release of Annual Report for Employment Quality of University Graduates (JXTH [2013] No.25), ordering universities to compile and release the employment quality report since 2013. As a private vocational college, Lingnan Institute of Technology in Guangdong Province has carried out the follow-up survey on graduates in consecutive four years as of the graduates of grade 2013, compiled and openly issued the survey report of employment quality of graduates in this college in strict accordance with the requirements of the Ministry of Education. Through deep analysis on the employment quality report, we have seen the school-running quality of private vocational colleges has made great achievements but still has some problems. We can take precautions and solve many problems in it through career planning education.

The research has chosen the three measurement indexes of employment quality, namely monthly income, specialty relevance and satisfaction degree of current employment status in the survey report of employment quality of graduates in grade 2016 in Lingnan Institute of Technology" for analysis and has established the supply and demand equilibrium model for the improvement of employment quality of private vocational colleges from the perspective of career planning according to the survey data in the career guidance service.

\section{OVERVIEW ON THE EMPLOYMENT, EMPLOYMENT QUALITY AND CAREER PLANNING}

The employment refers to "the economic activity that labors obtain corresponding salary or operating income through engaging in social work, including the amount of employment and the quality of employment. The amount of employment predominantly reflects the number of employed people, while the quality of employment mainly reflects the payment level, work environment, social security level and vocational development of labors". In terms of the amount of employment, the indexes selected by universities are alike, such as the total number of graduates, the number of people participating in employment and the rate of immediate employment of graduates. However, with regard to the quality of employment, the Ministry of Education does not give unified regulations on the measurement index of employment quality in the annual report of employment quality, so the measurement indexes of employment quality selected by universities are varied. Lingnan Institute of Technology mainly selects the three measurement indexes of employment quality, namely monthly income, specialty relevance and satisfaction degree of current employment status. 
Career planning means individuals combine with organizations and comprehensively analyze and balance according to their interests, hobbies, abilities and characteristics on the basis of evaluating, analyzing and summarizing the subjective and objective conditions of their career. Meanwhile, with the characteristics of era, they determine the optimum career goal according to the career orientation and make effective arrangements to achieve this goal.

\section{INVESTIGATION ON THE EMPLOYMENT QUALITY OF GRADUATES IN GRADE 2016}

It is impossible for universities to center on the quality of employment without the consideration of employment amount in the investigation on the employment quality, so this paper has conducted statistical analysis on the measurement indexes of employment quality and simple statistics on the measurement index of the amount of employment.

\section{A. Analysis on the Measurement Indexes for the Amount of Employment}

1) The total number of graduates: The total number of graduates in grade 2016 of Lingnan Institute of Technology is 5,382. Up to Dec.10th, 2016, 5,145 students had been qualified for graduation, while 237 graduates are unqualified for graduation.

2) Employment rate of graduates: The rate of immediate employment of graduates in grade 2016 of Lingnan Institute of Technology is $95.93 \%$ at a historical high, but efforts remain to be made to realize the employment of all graduates. The rate of immediate employment in the recent three years shows the tendency of increasing year by year, and the concrete data are shown as follows:

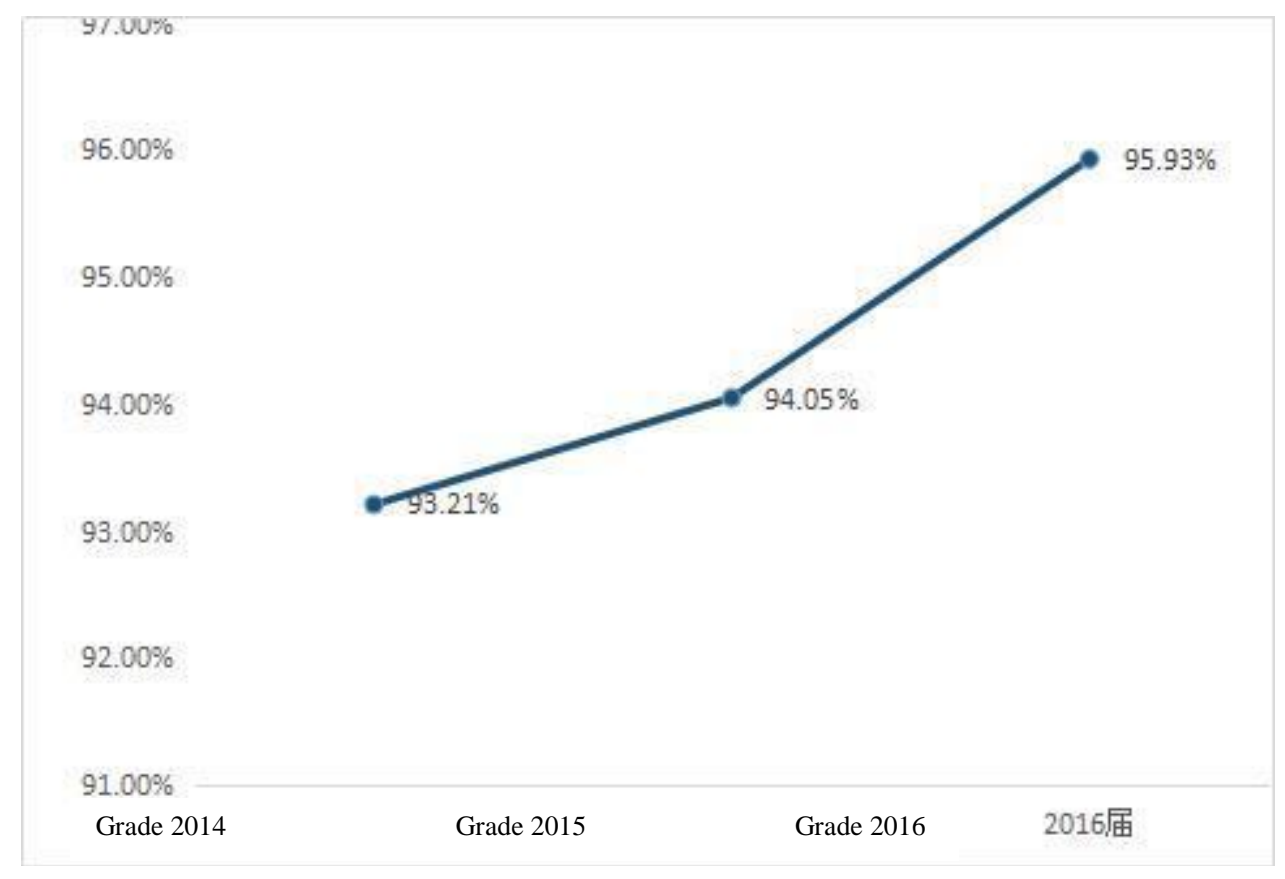

Fig. 1. Variation tendency of the rate of immediate employment.

At the meantime, the rate of immediate employment only shows graduates are able to be employed. The increasing rate of immediate employment year by year only reveals the proportion of graduates who can be employed is improved. No inevitable connection exists between the improvement of the rate of immediate employment and the elevation of employment quality.

Data source: Annual report of the employment quality of graduates in grade 2016 of Lingnan Institute of Technology

\section{B. Analysis on the Measurement Indexes of Employment} Quality

1) Analysis on the data of monthly income: The monthly income of graduates in grade 2016 of Lingnan Institute of Technology is 3,657 yuan, 125 yuan higher than the average level of the national higher vocational campus school, as shown in the figure: 


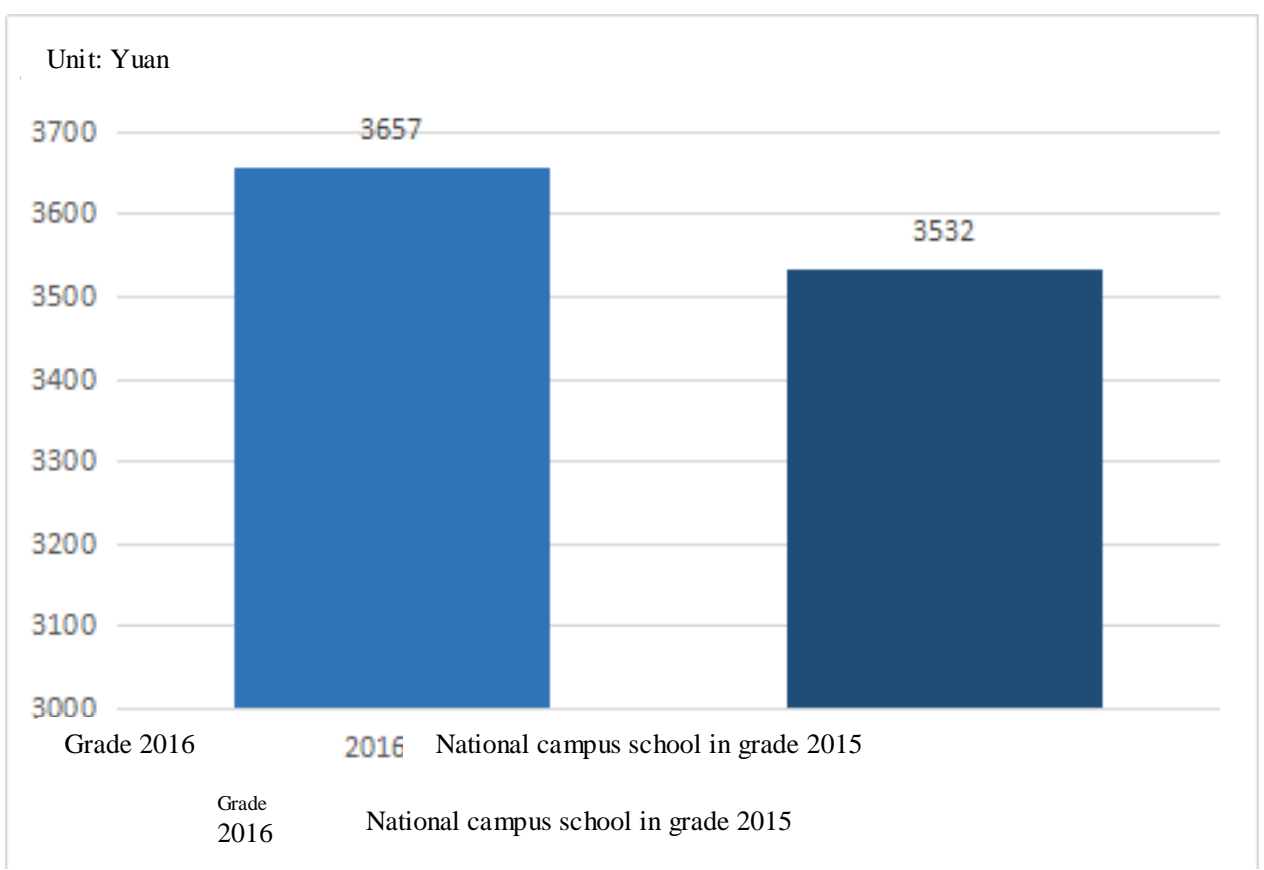

Fig. 2. Monthly income of graduates.

The monthly income of graduates in grade 2016 of the ${ }^{\text {b. }}$ Data source: Annual report of the employment quality of graduates in grade 2016 of Lingnan Institute of Technology school and colleges and the monthly income of graduates in grade 2015 are shown in the figure:

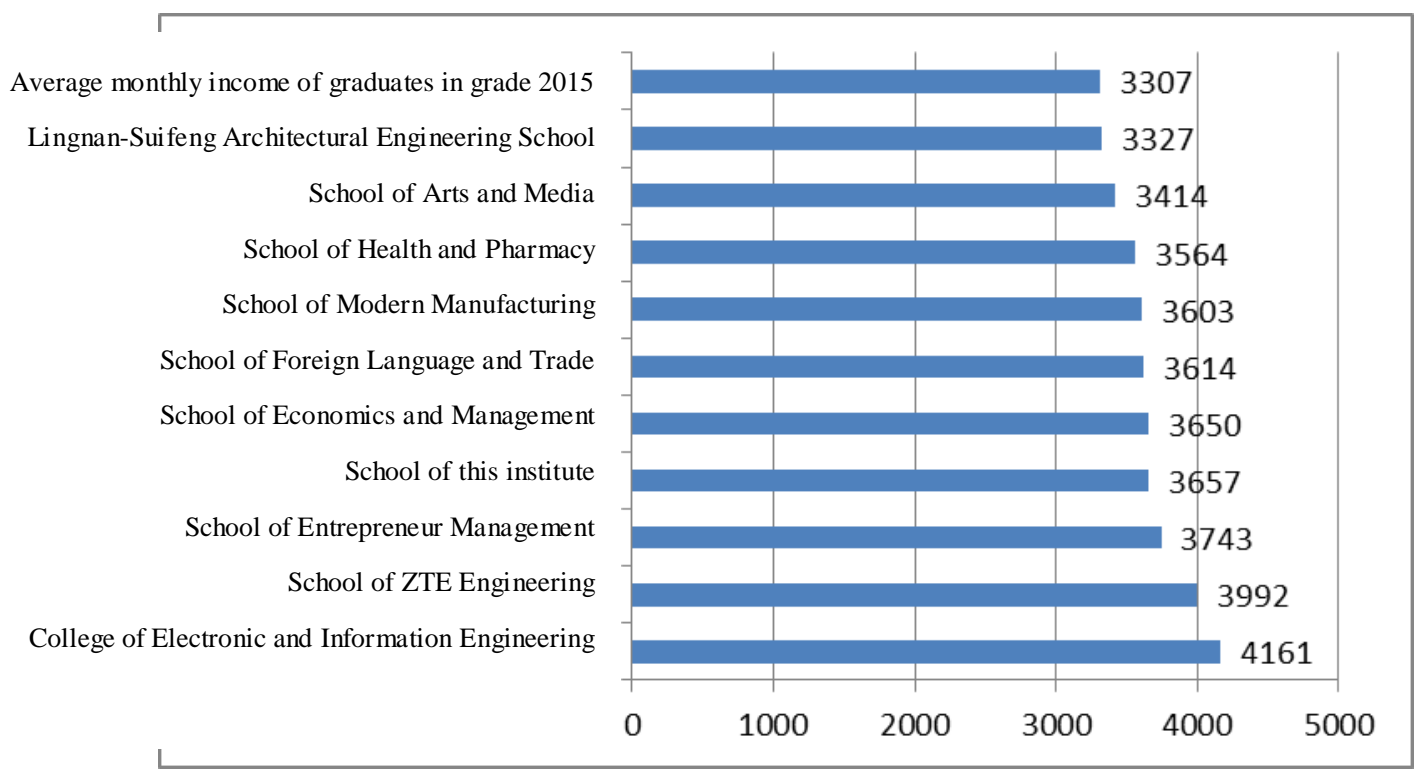

Fig. 3. Monthly income of graduates of colleges in the school and the monthly income of graduates in grade 2015 .

It reveals: the college that has the highest monthly income of graduates is the College of Electronic and Information Engineering (4,161 yuan), and the college that has the relatively low monthly income is the Lingnan-Suifeng Architectural Engineering School. The monthly income of graduates in grade 2016 is 3,657 yuan, 350 yuan higher than that of graduates in grade 2015 (3,307 yuan). At the same time,
Data source: Annual report of the employment quality of graduates in grade 2016 of Lingnan Institute of Technology the specialties that have the relatively high monthly income of graduates in grade 2016 are software technology (mobile internet) (4,795 yuan), software technology (international IT) $(4,768$ yuan), marketing (automobile service and evaluation) (4,587 yuan); the specialties that have the relatively low monthly income of graduates are project supervision $(2,900$ yuan) and decorative artistic design (interior design) (2,964 
yuan). Only with the measurement index of employment quality, namely the monthly income, we can see the quality of employment has been improved to some extent, but we must clearly see: at the level of college, only the monthly incomes of three colleges, namely College of Electronic and Information Engineering, School of ZTE Engineering and School of Entrepreneur Management exceed the average level of the school. The monthly income of other six schools is below 3,567 yuan, with the serious phenomenon of "being averaged". From the level of specialty, the monthly income of the specialty of project supervision that has the lowest monthly is only 2,900 yuan. The monthly income of 20 specialties is below the average level of the school (3,567 yuan).

2) Data analysis of specialty relevance: The relevance between work and specialty of graduates in grade 2015 of Lingnan Institute of Technology is the same as that of graduates in grade 2015 of national campus school, namely 62 percent. The relevance between work and specialty of graduates in grade 2016 is 63 percent, 1 percent higher than that of graduates in grade 2015 (62 percent) of this school. It is as shown in the figure:

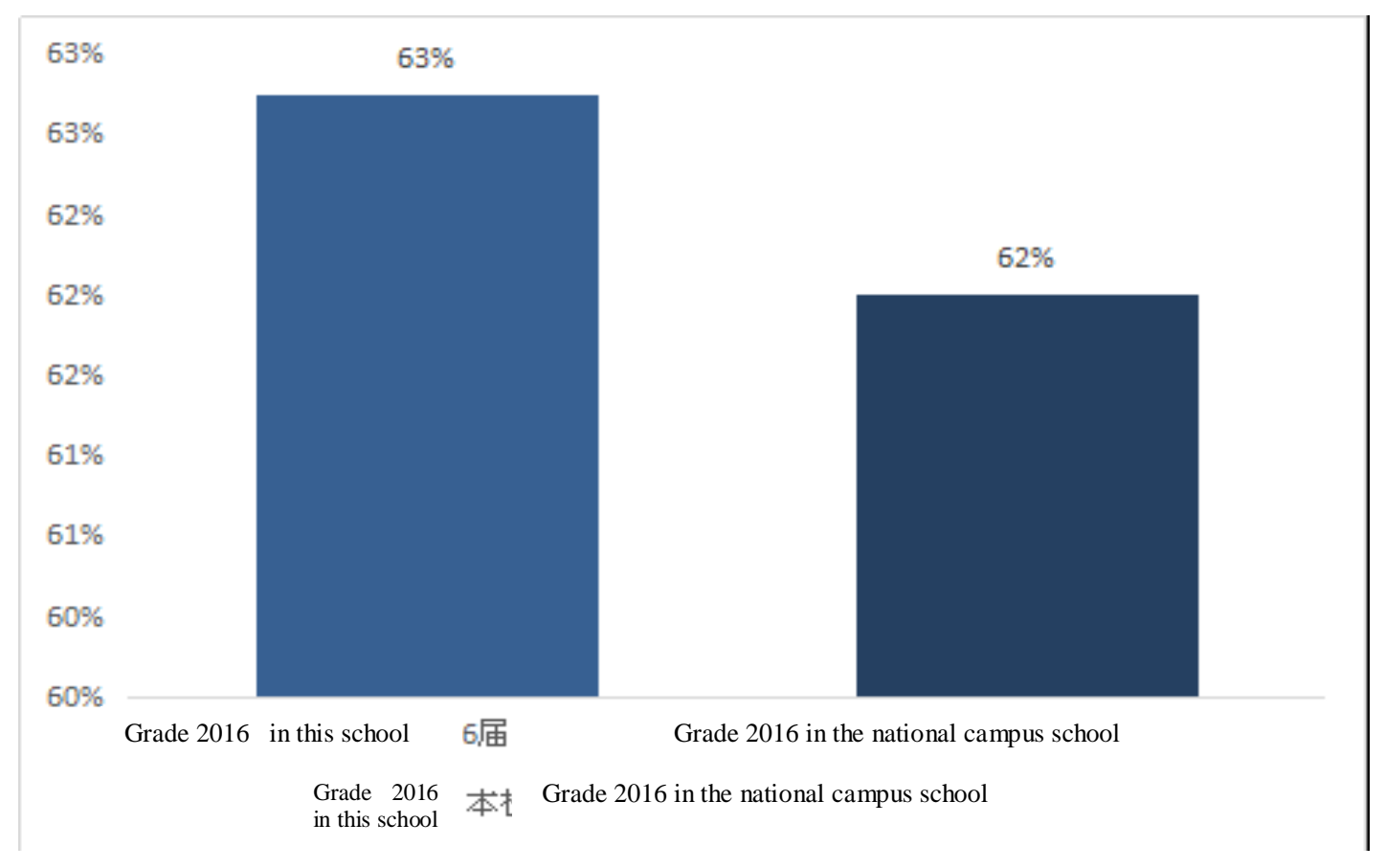

Fig. 4. Relevance between work and specialty.

d. Data source: Annual report of the employment quality of graduates in grade 2016 of Lingnan Institute of Technology

The relevance between work and specialty of graduates in grade 2016 of the school and colleges is as shown in the figure: 


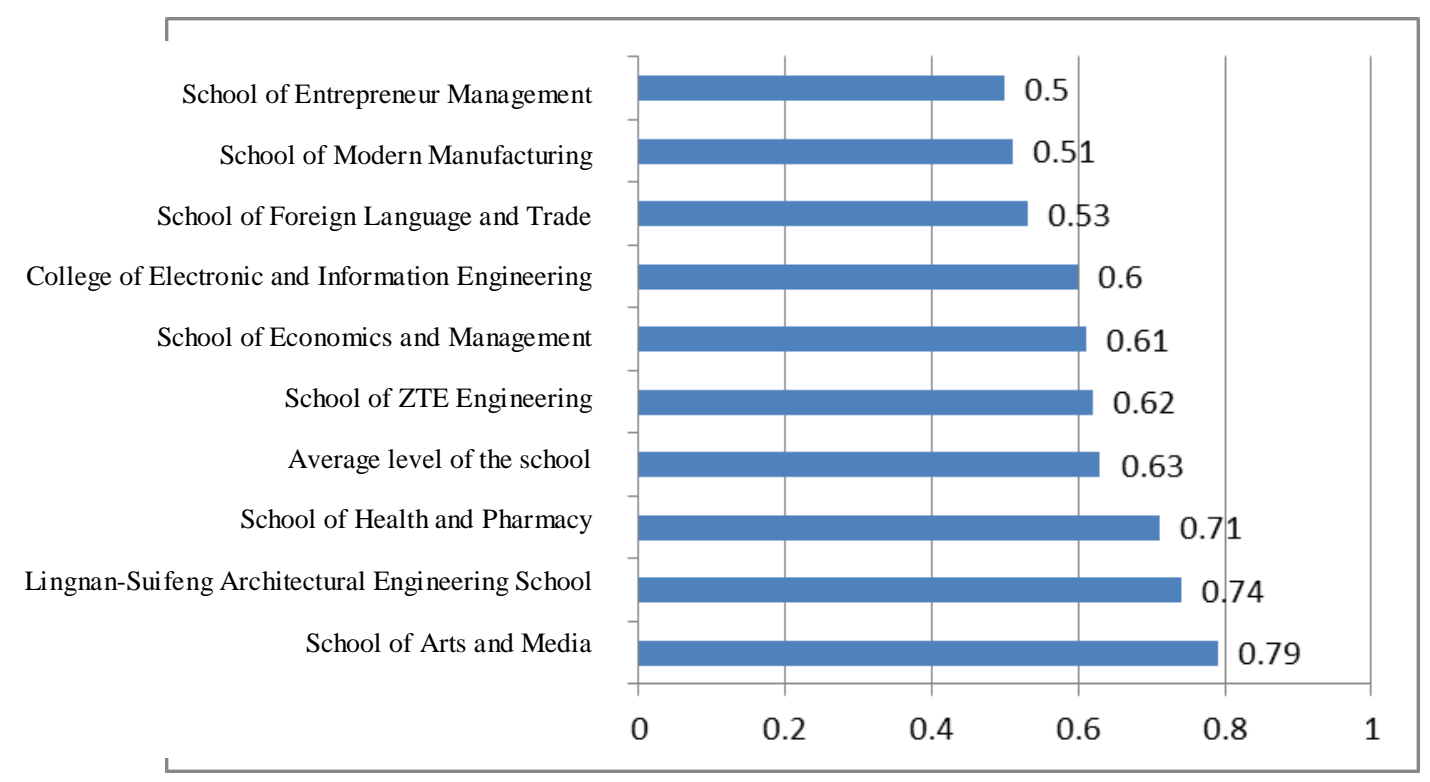

Fig. 5. Relevance between work and specialty of colleges.

It shows: The college that has the high relevance between work and specialty of graduates in grade 2016 is the School of Arts and Media (79 percent), and the colleges that have the low relevance between work and specialty are the School of Entrepreneur Management (50 percent), School of Modern Manufacturing (51 percent) and School of Foreign Language and Trade (53 percent). Only the School of Arts and Media, Lingnan-Suifeng Architectural Engineering School and School of Health and Pharmacy have the specialty relevance higher than the average level of this school, and the specialty relevance of six other colleges is below the average level of this school. At the meanwhile, the specialties that have high relevance between work and specialty in grade 2016 of this school are art and design (graphic design) (95 percent) and costume design ( 91 percent), and the specialties that have the relatively low relevance between work and specialty are Electronic Information Engineering and Technology (29 percent), Business Management (Chain Operation Management) (31 percent), International Business (Exhibition
Pnnual report of the employment quality of graduates in grade 2016 of Lingnan Institute of Technology Planning and Management) (33 percent) and International Business (International Trade) (33 percent). The specialty relevance of the Specialty of Electronic Information Engineering and Technology that has the lowest specialty relevance is 65 percent points lower than that of the Specialty of Art and Design (graphic design) that has the highest specialty relevance. It is evident that there is a large room for improvement of other specialties in the specialty relevance, the measurement index of employment quality.

3) Data analysis on the satisfaction degree of the current employment status: The satisfaction degree of the current employment status of graduates in grade 2016 of Lingnan Institute of Technology is 70 percent, 6 percent points higher than the satisfaction degree of the current employment status of graduates in grade 2015 (64 percent). It is shown in the figure: 


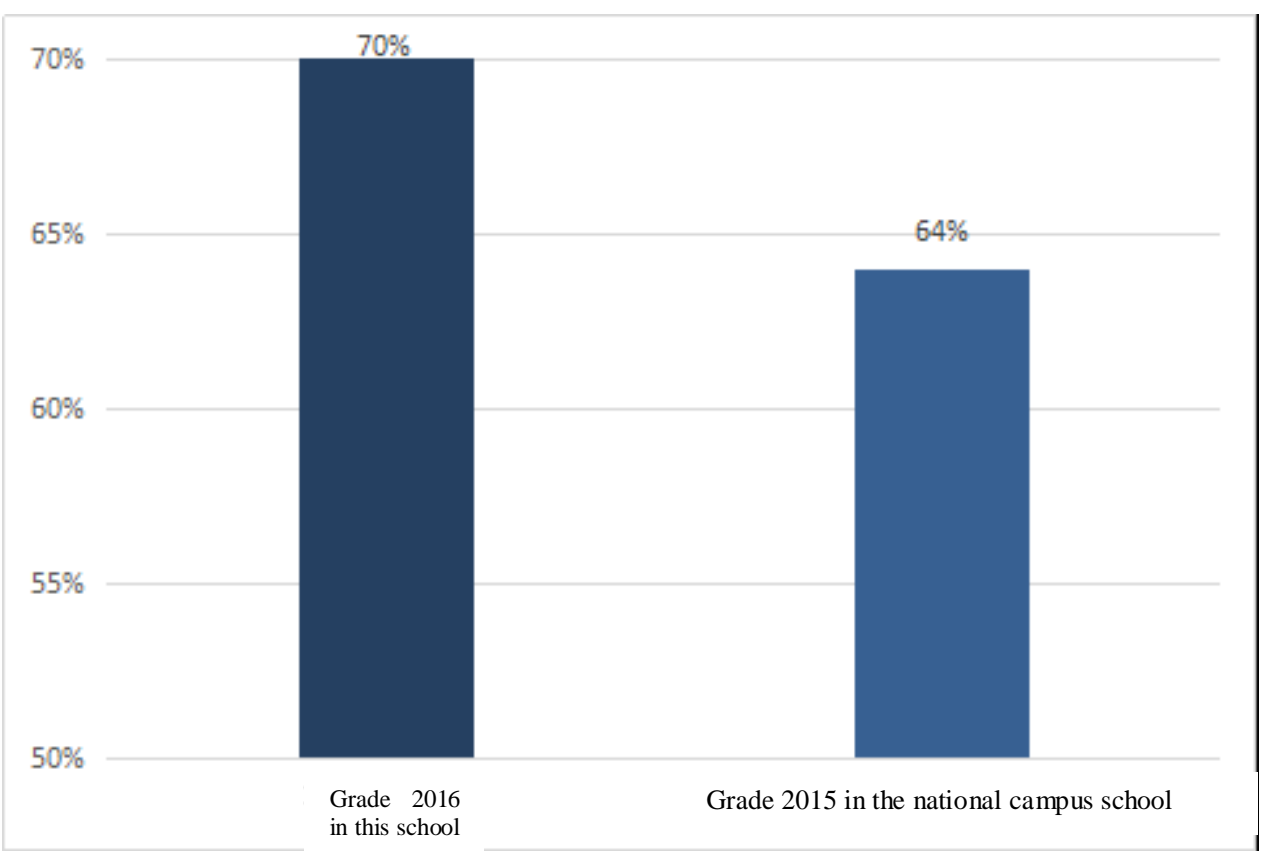

Fig. 6. Satisfaction degree of the current employment status.

${ }^{\text {f. }}$ Data source: Annual report of the employment quality of graduates in grade 2016 of Lingnan Institute of Technology

The satisfaction degree of current employment status of graduates in grade 2016 is 70 percent, 2 percent points higher than that of the grade 2015 (68 percent) of this school. The

School of ZTE Engineering

College of Electronic and Information Engineering

Lingnan-Suifeng Architectural Engineering School

School of Foreign Language and Trade

School of Economics and Management

School of Health and Pharmacy

Average level of the school

School of Modern Manufacturing

School of Arts and Media

School of Entrepreneur Management satisfaction degree of current employment status of graduates in colleges in grade 2016 is shown in the figure:

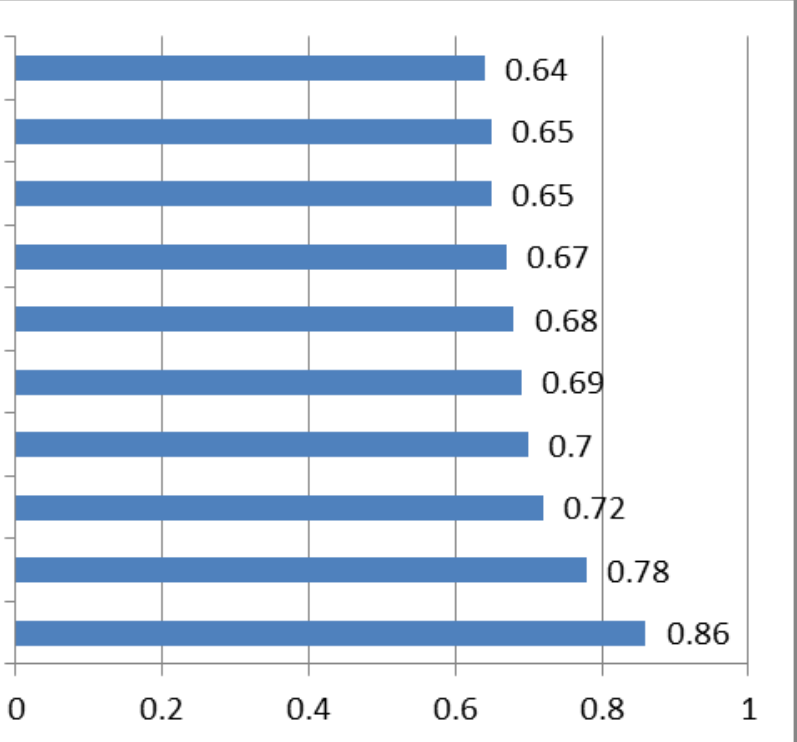

Fig. 7. Satisfaction degree of the current employment status of graduates in colleges.

It shows: The college that has the high satisfaction degree of current employment status of graduates in grade 2016 is the School of Entrepreneur Management (86 percent), and the college that has the low satisfaction degree of current employment status of graduates is the School of ZTE Engineering (64 percent). Only the satisfaction degree of employment of the three colleges, namely the School of Entrepreneur Management, School of Arts and Media and e: Annual report of the employment quality of graduates in grade 2016 of Lingnan Institute of Technology School of Modern Manufacturing is above the average level of the whole school, and the satisfaction degree of employment of other six colleges is below the average level of the whole school. At the same time, the specialties that have a relatively high satisfaction of the current employment status of graduates in grade 2016 are Art and Design (graphic design) (93 percent) and Business Management (entrepreneur management of small and medium-sized enterprises) (86 percent). The specialty that 
has the lowest satisfaction degree of the current employment status is Digit Control Technique (45 percent), and the specialties that have the satisfaction degree of current employment status of below 60 percent include English (59 percent), Software Technology (58 percent) and Pharmacy (57 percent). It unveils big differences exist in different specialties on the satisfaction degree of employment. There is large room to improve the measurement index of employment quality, namely the satisfaction degree of employment.

\section{Analysis on the Supply and Demand of Employment Guidance Service}

The overall satisfaction of the graduates in grade 2016 of Lingnan Institute of Technology for the employment guidance service is 81 percent, with 13 percent very satisfied, 68 percent satisfied, 16 percent unsatisfied and 3 percent very unsatisfied. As shown in the figure:

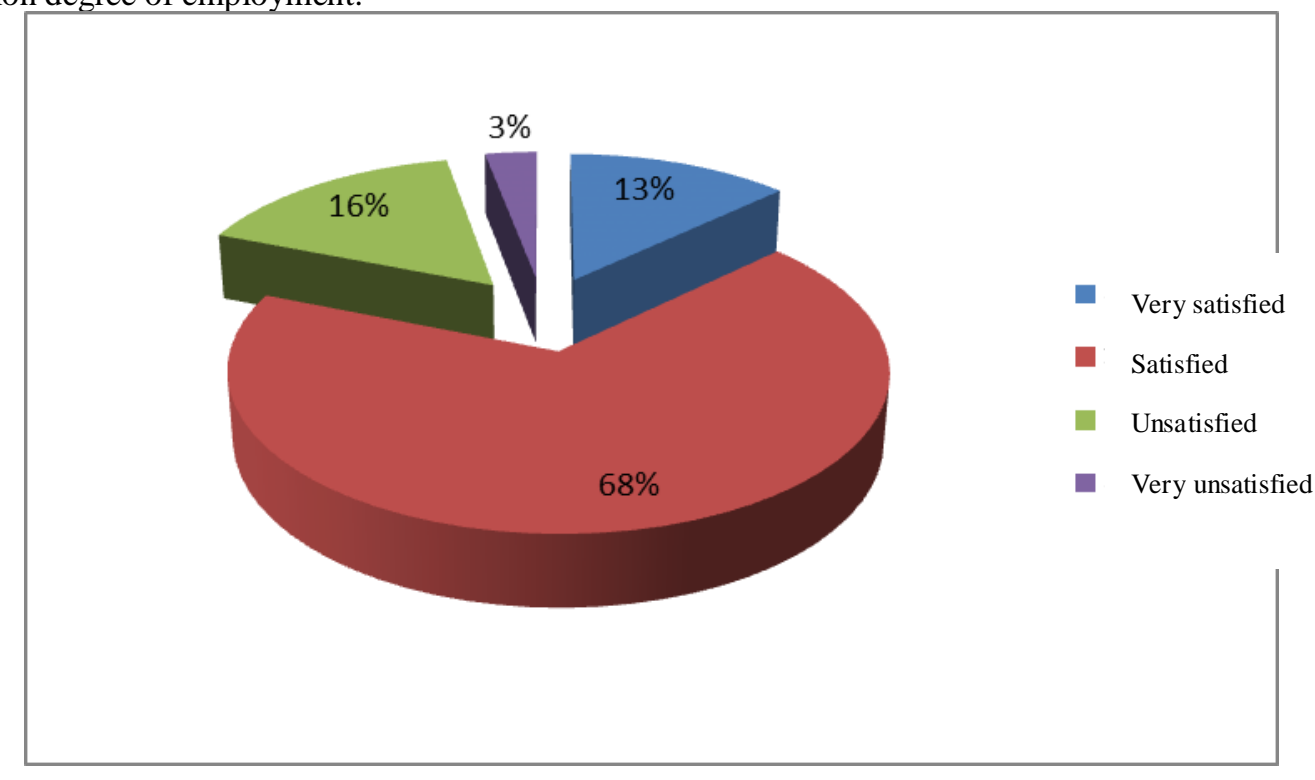

Fig. 8. Overall satisfaction degree of graduates for the employment guidance service.

The overall satisfaction degree of graduates in colleges in grade 2016 for the employment guidance service is shown in the following figure:

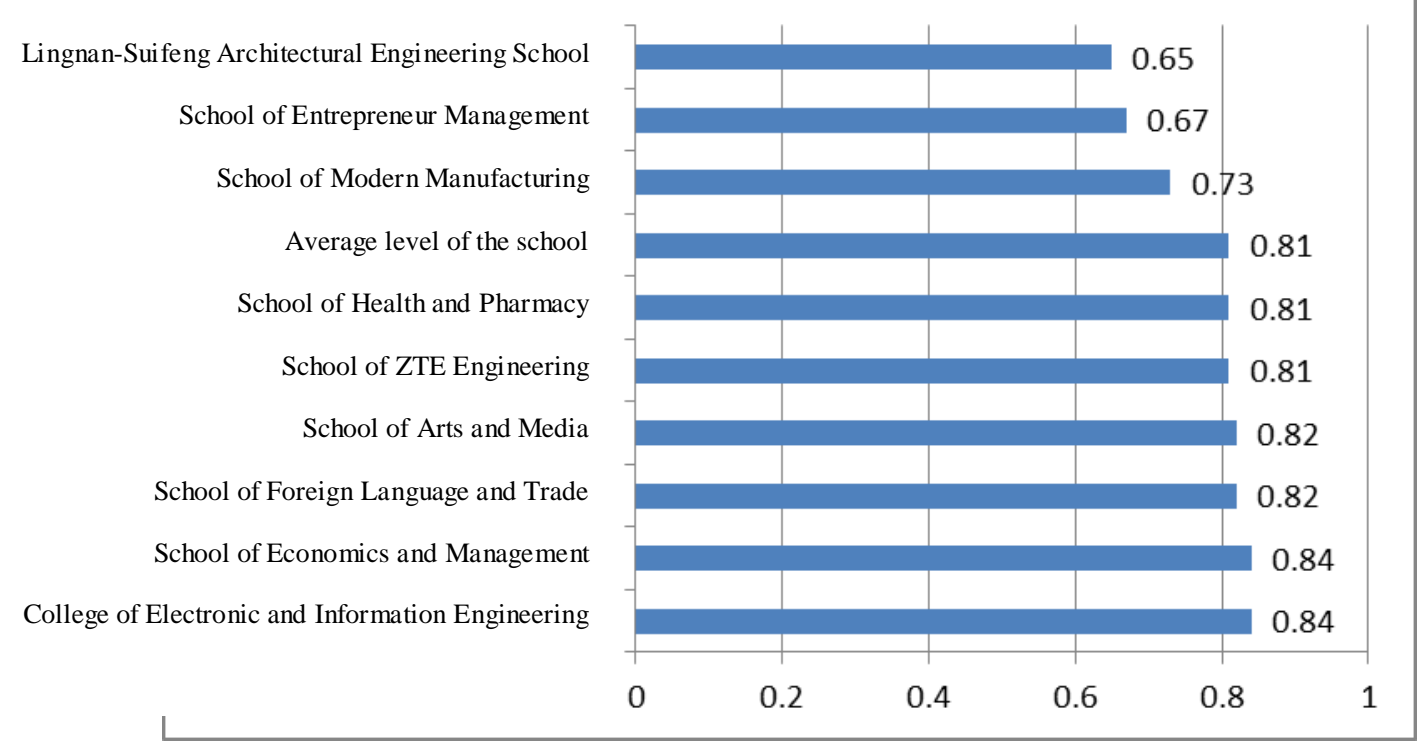

Fig. 9. Overall satisfaction degree of graduates in colleges for the employment guidance service.

\footnotetext{
${ }^{\text {i. }}$ Data source: Annual report of the employment quality of graduates in grade 2016 of Lingnan Institute of Technology
} 
It is observed that: The colleges that have a relatively high overall satisfaction degree of graduates in grade 2016 of our school for the employment guidance service are the College of Electronic and Information Engineering and School of Economics and Management (84 percent for both), and the colleges that have a relatively low overall satisfaction degree of the employment guidance service are Lingnan-Suifeng
Architectural Engineering School (65 percent) and School of Entrepreneur Management (67 percent). No colleges that have the overall satisfaction degree for the employment guidance service of overall 85 percent exist. The implementation of various employment guidance services and the evaluation of graduates are shown in the following figure:

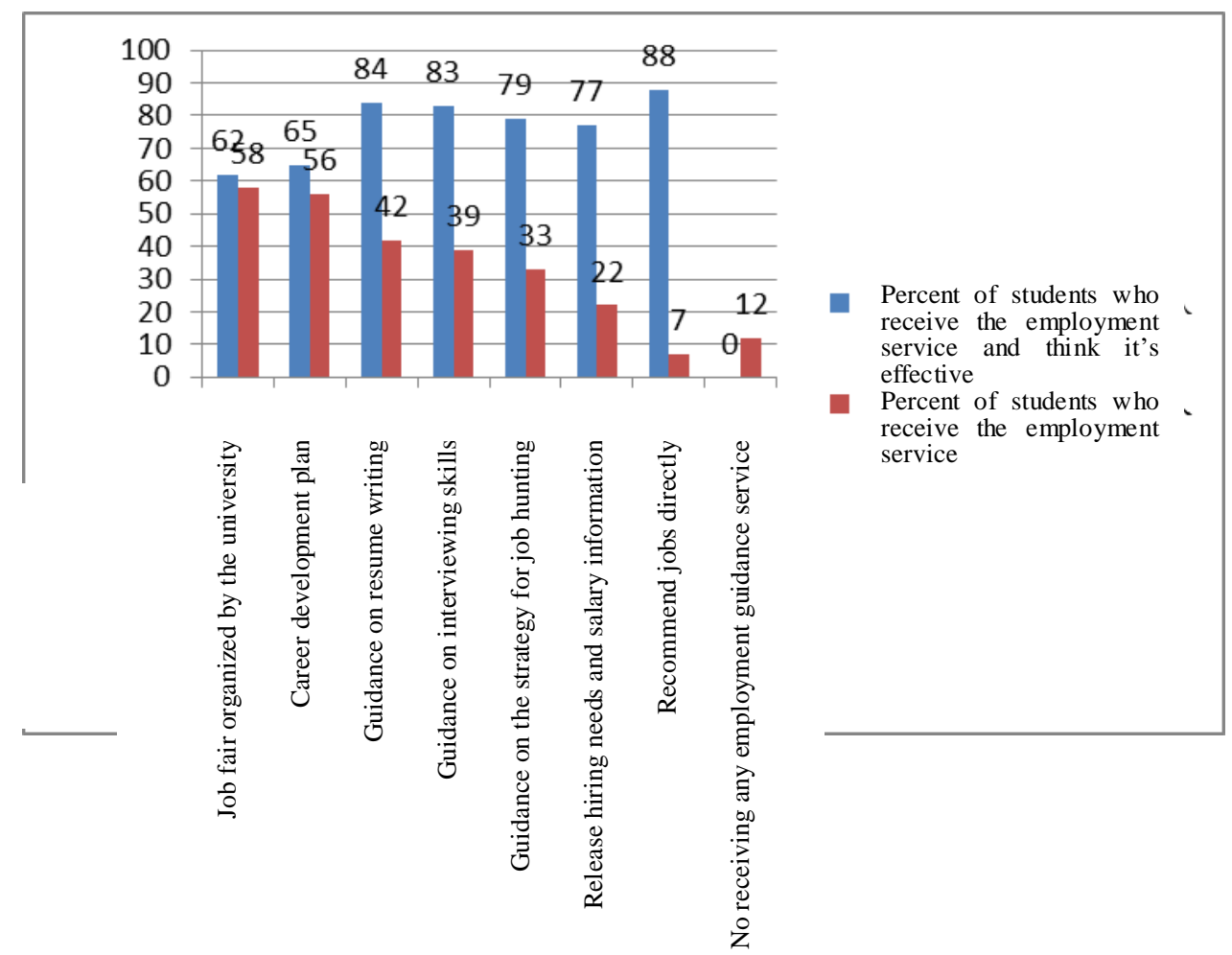

Fig. 10. Proportion of graduates who receive the employment guidance service and effectiveness appraisal (multiple choices).

It reveals: the major contents and forms of the employment guidance service in Lingnan Institute of Technology include: Organize job fair, career development plan, guidance on resume writing, guidance on interviewing skills, guidance on the strategy for job hunting, release of needs and salary information and direct recommendation of job. Graduates in grade 2016 who receive the employment service of "job fair organized by the university" account for the largest proportion (58 percent), and those receiving employment services of "career development plan" (56 percent), guidance on resume writing (42 percent), guidance on interviewing skills (39 percent), guidance on the strategy for job hunting (33 percent) and release of hiring needs and salary information ( 22 percent) as well as direct recommendation of jobs (7 percent) are in the second place. 12 percent of students observe they "have not received any employment guidance service". When evaluating the effectiveness of employment service, the graduates in grade 2016 think the employment service of direct recommendation of jobs is the most effective ( 88 percent), then the second ones are the guidance on resume writing ( 84 e: Annual report of the employment quality of graduates in grade 2016 of Lingnan Institute of Technology percent), guidance on interviewing skills (83 percent), guidance on the strategy for job hunting (79 percent), release of hiring needs and salary information (77 percent), career development plan (65 percent) and job fair organized by universities (62 percent). The above data show the overall satisfaction degree for the employment guidance service of the school is relatively high. We can pay more attention to the forms and contents of employment service on the basis of accurately acquiring students' needs and create a series of the service system of employment guidance course that is useful and interesting in students' eyes, in order to further improve the satisfaction degree and effectiveness of employment guidance service. 
IV. ESTABLISH THE SUPPLY AND DEMAND EQUILIBRIUM MODEL FOR THE IMPROVEMENT OF EMPLOYMENT QUALITY UNDER THE PERSPECTIVE OF CAREER PLANNING

\section{A. Ideas for the Improvement of Employment Quality}

At present, most researches on the improvement of employment quality have designed sound course systems from the perspective of supply and demand, namely the course construction. However, the sound course system does not represent the improvement of employment quality because most students learn passively with the idea that the school forces me to learn. To arouse students' enthusiasm about learning and turn "force me to learn" into "I want to learn", it's necessary to let students realize the knowledge and skills required in the future employment and the obstacles to be swept away and evoke their eagerness for the course provided. The learning initiative of students is the prerequisite for the sound course system to play the role of improving employment quality.

The supply and demand has been researched according to the idea of supply and supply balance in economics. On one hand, the research concentrates on using the theory of career planning to help students know clearly about them and their demands to foster the impetus of learning and proactively learn various courses provided by the school and let the sound course system play the role of improving employment quality. On the other hand, on the basis of the requirements of students and the society, the course system that conforms to the practical situation of private vocational colleges is set to provide effective "supply" for students.

\section{B. Establish the Supply and Demand Equilibrium Model For the Improvement of Employment Quality}

Matching the career planning path with the employment guidance course makes students have effective "demands" through the career planning and obtain the effective "supply" from the course system of employment guidance of the school to realize the balance between supply and demand. The learning state of students changes from "force me to learn" to "I want to learn"; the course provided by the school changes from "force students" to learn to the proactive "enthusiasm" of students in learning. The supply and demand balance between the "demand" of students and the "supply" of the course system of employment guidance of the school will be realized under the perspective of career planning. The supply and demand equilibrium model for the improvement of employment quality is shown in the following figure: 


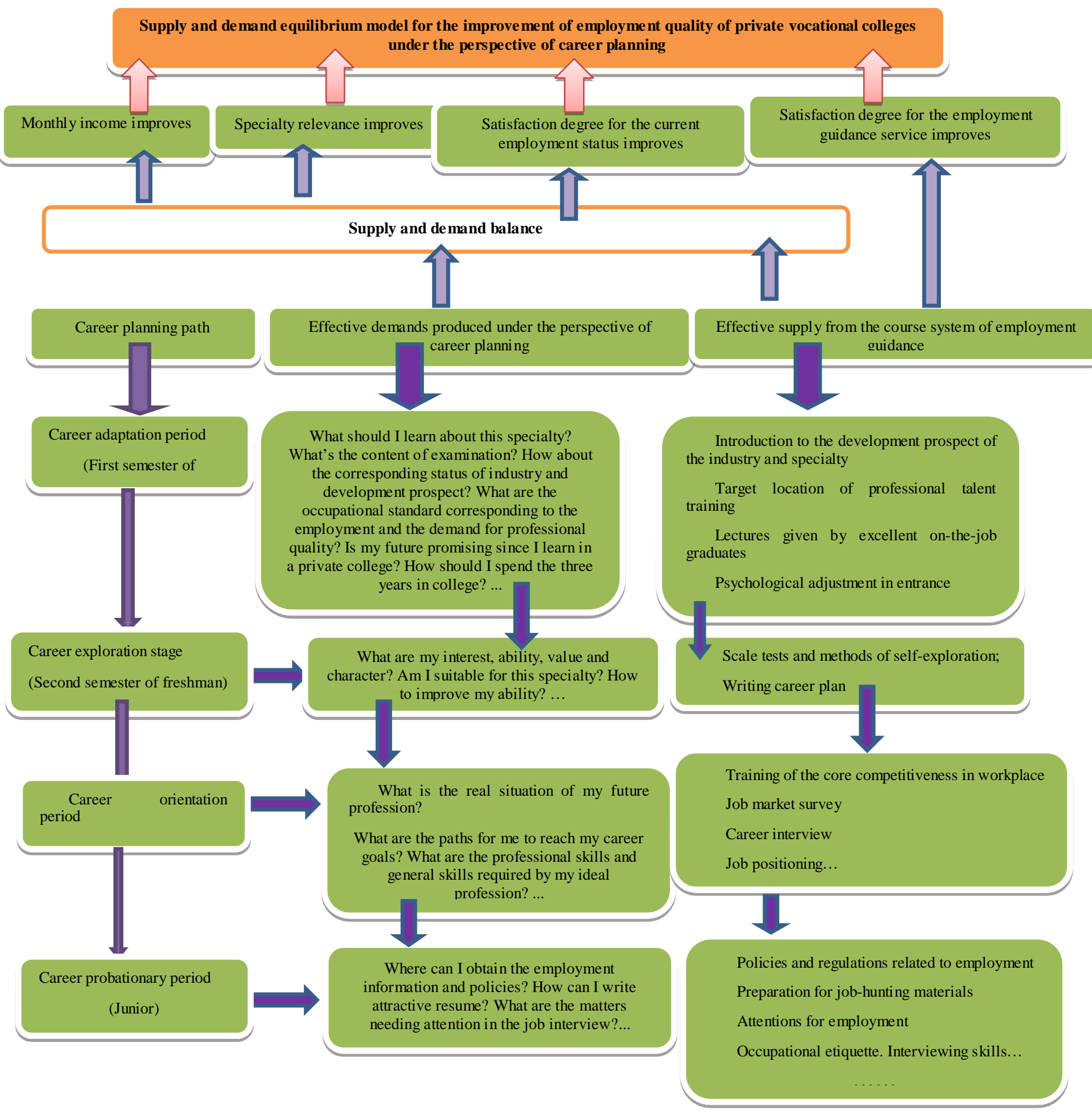

Fig. 11. Supply and demand equilibrium model for the improvement of employment quality of private vocational colleges under the perspective of career planning.

\section{Explanation on the Supply and Demand Equilibrium Model for the Improvement of Employment Quality}

\section{1) Career adaptation period: First semester of freshman}

a) Effective demands produced under the perspective of career planning: What should I learn about this specialty? What's the content of examination? How about the corresponding status of industry and development prospect? What are the occupational standard corresponding to the employment and the demand for professional quality? Is my future promising since I learn in a private college? How should I spend the three years in college? ...

b) Effective supply from the course system of employment guidance: Introduction to the development 
prospect of the industry and specialty, target location of professional talent training, lectures given by excellent onthe-job graduates, psychological adjustment in entrance and guidance on personal career planning...

c) Supply and demand balance: matching of effective supply and effective demand: The initial stage of entrance is the period for students to adapt to the environment. Many freshmen of private vocational colleges have not get rid of the shadow of failing in the college entrance examination at the same time are confused about the transformation from the strict management in senior high schools to the free and relax management in the college. In this period, we must strengthen the guidance on students and help them break away from psychological shadow and confuse and establish the concepts such as how to learn in the college and how to make good use of college and form the consciousness of career planning. The practice of Lingnan Institute of Technology has certain referential significance, and the specific practice is as follows:

First of all, the entrance education of freshmen can be taken as the teaching content of the course "Career Development and Employment Guidance" for implementation and assessment. Successful entrepreneurs and upperclassmen (learning adept) and outstanding graduates can be invited to give lectures and have informal discussions; students can also be organized to visit enterprises, understand or experience the process of practical training; the competitions and innovative products of upperclassmen can be introduced to let students understand their specialty and like it, arouse their learning intention and improve their learning interests. The entrance education of freshmen can be divided into the four modules as shown in "Table I":

TABLE I. CONCRETE CONTENTS OF THE ENTRANCE EDUCATION OF Freshmen

\begin{tabular}{|c|c|c|c|}
\hline No. & Module & Main Contents and Demands & $\begin{array}{c}\text { Imple menting } \\
\text { Form }\end{array}$ \\
\hline 1 & $\begin{array}{l}\text { Professional } \\
\text { education and } \\
\text { teaching } \\
\text { management }\end{array}$ & $\begin{array}{l}\text { (1)Introduction to the industry and specialty: (1) Introduce information about the current situation and } \\
\text { development prospect of the industry and specialty, market demands for talents of this specialty and the career } \\
\text { choice of graduates; (2)Introduce information about the occupational standard of jobs related to the specialty and } \\
\text { demands of professional quality. } \\
\text { (2)Explanation of Specialty Norm: (1)Introduce characteristics of vocational education; (2) Introduce norms, target } \\
\text { location of talent training and course system of this specialty; (3) Introduce the training model of phased } \\
\text { professional quality, learning methods and teaching models during the college of three years for students. } \\
\text { (3)Corresponding relation and assessment of the expected learning outcomes of specialty and the expected } \\
\text { learning outcomes of required course: (1)Let students explicitly know the expected learning outcomes of this } \\
\text { specialty under DQP system; (2)Introduce the corresponding relation between the expected learning outcomes of } \\
\text { specialty and courses and its evaluation ways. } \\
\text { (4)Introduce the school-running characteristics of second-class colleges and its teaching management system. } \\
\text { Show school-running characteristics and effects and learn the enforcement regulations of the credit system and } \\
\text { systems of student status management and result and GPA management. }\end{array}$ & Lecture \\
\hline 2 & $\begin{array}{l}\text { Enter the } \\
\text { library }\end{array}$ & How to effectively make use of resources in the library & $\begin{array}{l}\text { Lecture } \\
\text { Visit }\end{array}$ \\
\hline 3 & $\begin{array}{l}\text { Student } \\
\text { management }\end{array}$ & $\begin{array}{l}\text { (1)Get familiar with Lingnan campus culture: Center on the school's student management model and combine } \\
\text { with the idea of learned and accomplished education, strengthen the construction of class culture and cultivate a } \\
\text { good class atmosphere and school spirit. } \\
\text { (2)Learn of Student Manual: Combine with the professional learning plan and focus on learn the school's policies } \\
\text { about award and subsidy, appraisal and punishment systems. } \\
\text { (3)Safety and discipline education: Strengthen the education with themes of safety and discipline on students and } \\
\text { create a good learning and living environment. } \\
\text { (4)Code of conduct on campus: Combine with the code of conduct on campus such as eight rituals on campus } \\
\text { and network morals on campus to publicize in the form of micro-course popular among students. } \\
\text { (5)Establishment and selection of class committee: Strengthen the class construction and select class leaders and } \\
\text { focus on train backbone of students' thought. }\end{array}$ & $\begin{array}{l}\text { Lecture } \\
\text { Class meeting }\end{array}$ \\
\hline 4 & $\begin{array}{l}\text { Guidance on } \\
\text { students' } \\
\text { career } \\
\text { planning }\end{array}$ & $\begin{array}{l}\text { (1) Guide students to learn goal planning and grasp the plans for three-year professional learning and skill } \\
\text { improvement; (2)et students clearly know the importance and far-reaching significance of "innovative, creative } \\
\text { and entrepreneurial" education (training); (3) Understand characteristics of future profession and think about the } \\
\text { relation between the future ideal profession and the specialty and gradually establish long-term and stable } \\
\text { development objective; (4)Guide students to plan their life according to their real situation to make the learning } \\
\text { more purposeful and enthusiastic. }\end{array}$ & $\begin{array}{l}\text { Report } \\
\text { Lecture } \\
\text { Discussion } \\
\text { Activity }\end{array}$ \\
\hline
\end{tabular}

The entrance education of freshmen on one hand can let freshmen understand their school and the training program, teaching plan, learning results and assessment and job orientation of this specialty to better adapt to the learning and living environment in the college; on the other hand, it enables freshmen to understand the contents and significance of career planning and establish the consciousness of career planning.

\section{2) Career exploration stage: Second semester of freshmen}

a) Effective demands produced under the perspective of career planning: What are my interest, ability, value and character? Am I suitable for this specialty? How to improve my ability? ... 
b) Effective supply of the course system of employment guidance: Scale tests and methods of selfexploration, writing career plan...

c) Supply and demand balance: match effective supply with effective demand: Students at this stage have just complete the transformation and basically adapted to the learning and living environment of the college and have a macro cognition on the college. In this stage, we can guide students to explore and understand themselves through theories and tools of career planning. They will have a correct self-understanding through comprehensive selfanalysis. Specifically, we can implement through interest exploration, ability exploration, value exploration, character exploration and other self-cognition methods.

\section{- Interest exploration}

Interest refers to the psychological disposition that individuals strive to understand and grasp something and frequently participate in activities. People will become more concentrated, have a strong will and active mind and acquire pleasure if they do something in which they are interested. At present, the most extensively-used interest exploration tool is the vocational interest theory raised by Holland, a psychology professor of Johns Hopkins University in America, in 1959. Holland has concluded six personality types: Realistic personality type, research-based personality type, artistic personality type, social personality type, enterprise-based personality type and conventional personality type. Holland proposes, "People will be more satisfied and have a feeling of control if they choose the job in which they are interested". Students can understand the work that is suitable for their interests or personality characteristics through interest exploration tools through Holland vocational interest tests to effectively improve the measurement indexes of employment quality such as income, specialty matching rate and job satisfaction.

\section{- Ability exploration}

Abilities are inborn and acquired via cultivation. The degree of freedom of people on career choice depends on the ability and quality of a people to a large extent. Except for understanding the abilities, students must understand the skills they lack on vocational development and learn to offset their weakness via the strong points of them. Meanwhile, we have to understand the skill demand of dispositional profession through using related resources and methods and the skills to be developed to be qualified for the favored job. At present, the methods used for capability evaluation mainly include KASH evaluating method, evaluation method of ability exploration table and achievement event analysis method. The major method of improving capacity includes KST method. College students have to comprehensively evaluate their capacity and grasp methods of improving their vocational ability. In addition, they must have the courage and enterprise of doing grass-roots work. With the ability exploration tools, students will effectively enhance measurement indexes of employment quality of employment rate, specialty matching rate and job satisfaction degree.
Values are principles, norms or characters to which people pay attentions in job and life. As a faith and attitude of people toward profession, the occupational values have determined people's career expectation and influenced people's selection on career direction and career goal. Few jobs can completely meet all the values of a person, so students need to clarify and sort their values so that they will make their choice. At present, thirteen values proposed in the book of the Nature of Human Values published by Milton Rokeach, an American psychologist in 1973 have the relatively extensive influence. We can let students choose their occupational values from the three values. A clear occupational value will improve the satisfaction degree of the current employment status.

\section{- Character exploration}

Character refers to the individual mental characteristics shown by a person's stable attitude and conventional behavior pattern in the real life. Psychologists hold the opinion that we can choose professions according to our character to realize the harmony between us and job, so that we can control job with high proficiency and improve the job satisfaction degree. Occupational character refers to people's stable psychological features related to profession and formed in the long-term specified working life. In the exploration of occupational character, the MBTI theory is widely used. It describes occupational character from four dimensions, namely the tendency of attitude, information reception, information access and mode of action. Students will acquire the code of MBTI formed by four letters through test. There are 16 monograms corresponding to 16 occupational characters that are suitable for some jobs respectively. Except for MBTI, the methods of character exploration also include DISC test and Sudoku personality test. These character exploration tools help students to clearly know the possible best ways of doing things and effectively improve the measurement indexes of employment quality like the specialty matching rate and satisfaction degree of current employment status.

\section{- Other self-recognition methods}

In the process of self-exploration, except for the observation of four aspects namely interest, ability, value and character, we can strengthen self-recognition under the help of others and objective evaluating means to integrate subjective and objective analysis. The methods of subjective analysis include: 360-degree round evaluation method, showcase method, professional consultation method and selfreflection and comparison method of others. The objective analysis method is mainly the professional evaluation method. Except for Holland's test of occupational interest type, professional value test, DISC character test, MBTI test and vocational ability test. Test scales frequently used at abroad also include career belief questionnaire, career decision-making scale, career interest scale, career development questionnaire, and career maturity questionnaire and career combination card.

- Value exploration 


\section{3) Career orientation period: sophomore}

a) Effective demands produced under the perspective of career planning: What is the real situation of my future profession? What are the paths for me to reach my career goals? What are the professional skills and general skills required by my ideal profession? ...

b) Effective supply of the course system of employment guidance: Training of the core competitiveness in workplace, job market survey, career interview and job positioning...

c) Supply and demand balance: Match effective supply with effective demand: Students have had a preliminary understanding of the industry or post suitable for them to engage and their advantages and disadvantages. Next, they will deeply understand the industries or posts through exploring the world of work. After exploring the world of work, they will know the description of job suitable for them to engage, core job contents, career development prospect, salary package, post setting, entrylevel job, career development channel, career model character, typical day of job, demands for career general quality, basic ability, work and way of thinking as well as inner demands for individuals, et al.

We can explore the world of work through many ways. For example, we can understand the classification of jobs and description of various jobs through Jobsoso website; understand the demands of employers for posts through enterprise' official websites and professional recruitment websites; understand the occupational information of different industries through We-Media such as WeChat and Weibo; understand the world of work through the interview of career character and resources around us.

Exploring the world of work helps students clearly know the basic quality and skills required by each post and find their shortcomings. Students will train the core competitiveness of workplace and strengthen their competitiveness by virtue of the studious learning in the second year of college. Except for improving the measurement index of employment amount like the rate of immediate employment, it will effectively improve the measurement indexes of employment quality such as specialty matching rate and satisfaction degree of current employment status.

\section{4) Career Probationary Period: Junior}

a) Effective demands produced under the perspective of career planning: Where can I obtain the employment information and policies? How can I write attractive resume? What are the matters needing attention in the job interview? ...

b) Effective supply of the course system of employment guidance: Policies and regulations related to employment, preparation for job-hunting materials, attentions for employment, occupational etiquette and interviewing skills... c) Supply and demand balance: Match effective supply with effective demand: The former two years of learning in the college makes students have a relatively comprehensive understanding of their future career and relatively ideal jobs or posts suitable for them. In the first semester of junior, students can further train comprehensive abilities necessary in workplace such as teamwork and time management and obtain job qualification certificates required by the target job. In the second semester of junior, they can proactively participate in professional practice and training which contribute to the adjustment of employment mentality and the improvement of occupational skills. In addition, they can learn resume making, workplace etiquettes, interviewing and job-hunting skills to prevail in the interview. At the meantime, they have to pay attention to policies and regulations related to employment and make use of policy resources at national, local and school levels to assist the employment.

\section{CONCLUSION}

We should heavy responsibilities in the improvement of the employment quality of private vocational colleges, which is a systematic project. The future researches can set about from the following aspects: First of all, the research has not involved the construction of concrete professional course but only focused on evoking students' effective demands from the perspective of career planning theory. Therefore, it has only established the effective "supply" regarding the course system of employment guidance. Future researches can bring students' professional demand and supply into the research scope and then establish a more systematic supply and demand equilibrium model for the improvement of employment quality. In the second place, the research only roughly designed the effective supply of the school, namely the course system of employment guidance, without involving the measures in guaranteeing the teaching effects of sound course systems designed. In the future, we can research on establishing the guarantee system of teaching quality from the course service of employment guidance provided by private vocational colleges.

\section{REFERENCES}

[1] Cui Jingyi. Discussion on Improving the Employment Quality of College Students via Improving the Career Planning Education [J], the Science Education Article Collects, 2016, (8) 136-137 崔静怡. 浅谈从完善职业生涯规划教育入手提高大学生就业质量 [J].科教 文汇.2016，（8）136-137

[2] Sun Hairong. Research on the Influence of Career Management on Students' Employment-Based on the Employment Quality of College Graduates [J], China's Manpower Resources Development, 2014, (19) 85-87 孙海荣. 职业生涯管理对学生就业的影响研究基于高校毕业生就业质量的实证调查 $[\mathrm{J}]$. 中国人力资源开 发.2014, (19) 85-87

[3] Nie Rong, Wen Aiai. Research on the Career Planning Course Based on the Improvement of Employment Quality [J], Business Administrator, 2016, (12) 467 聂榕, 文爱爱. 基于提升就业质量的 职业生涯规划课程研究 [J].经营管理者. 2016, (12) 467

[4] Zhang Jun. Influence of Career Planning on Improving Students' Employment Rate and Employment Quality [J], Heilongjiang Foreign Economic Relations and Trade, 2011, (1) 130 张军.职业生涯规划对 
提高大学生就业率与就业质量的影响 [J]. 黑龙江对外经贸.2011. (1) 130

[5] Hu Tingsheng. Career Planning and Management of College Students $[\mathrm{M}]$, Sun Yat-sen University Press, February 2015 edition 胡庭胜.大 学生职业生涯规划与管理 [M].中山大学出版社, 2015 年 2 月版

[6] Written by Brad Harrington,Douglas T.Hall, translated by Zhang Xing and Zhang Lu. Career Planning and Management [M], China Machine Press, January 2013 edition Brad Harrington, Douglas T.Hall 著, 张星 张璐译.职业生涯规划与管理 [M].机械工业出版 社, 2013 年 1 月版 